\title{
Çevrimiçi alışverişte sepeti terk etme ölçeğinin Türkçeye uyarlanmasi
}

\section{Adaptation of shopping cart abandonment scale in online shopping to Turkish}

1 Doktora Öğrencisi, İstanbul Aydın Üniversitesi, İstanbul, Türkiye,

esingenc@stu.aydin.edu.tr

ORCID: 0000-0003-4268-1361

2 Doç. Dr., İstanbul Aydın Üniversitesi, İstanbul, Türkiye,

ilkaykaraduman@aydin.edu.tr

ORCID: 0000-0003-4314-7590

3 Doktora Öğrencisi, İstanbul Aydın Üniversitesi, İstanbul, Türkiye,

aysegulalibasoglu@stu.aydin.edu.tr

ORCID: 0000-0002-9625-0332

Sorumlu Yazar/Corresponding Author:

Esin Çavuş Genç,

İstanbul Aydın Üniversitesi, İstanbul, Türkiye,

esingenc@stu.aydin.edu.tr

Başvuru/Submitted: 23/05/2021

Revizyon/Revised: 30/06/2021

Kabul/Accepted: 25/07/2021

Yayın/Online Published: 25/09/2021

\author{
Esin Çavuş Genç ${ }^{1}$ \\ İkay Karaduman² iD \\ Ayşegül Özkan ${ }^{3}$
}

Öz

Bilindiği üzere günümüzde artan bir hızla geleneksel alışverişe bir alternatif olarak çevrimiçi alışverişin payı gün geçtikçe artmaktadır. Geleneksel alışverişte müşterilerin bir alışveriş sepetine doldurdukları ürünleri satın almadan bırakmaları ender rastlanan bir durumken; çevrimiçi alışverişte her beş alışveriş sepetinden dördü terk edilmektedir. Bunun nedenlerinin araştırılması ve azaltılması hem akademisyenler hem de işletmeler açısından büyük önem arz etmektedir. Bu çalışmada KukarKinney ve Close (2010) tarafından geliştirilen "Alışveriş Sepeti Terk Etme Oranı Ölçeği"' nin Türkçeye uyarlanması hedeflenmiştir. Analizler basit tesadüfi örneklem ile gönüllü katılımcıların olduğu üç farklı örneklem üzerinde yapılmıștır. Araștırmanın örneklemi, Türkiye' deki çevrimiçi alıșveriş yapan bireylerden oluşmaktadır. Analizde güvenirlik analiz, frekans analizi, faktör analizi, KFA ve DFA'dan faydalanılmıștır Yapılan analizler sonucunda 5 faktörlü ve 17 maddeli bir ölçek elde edilmiștir. Elde edilen bu ölçeğin araştırmalarda kullanılmasının literatürdeki boşluğa fayda sağlayıcı düşünülmektedir.

Anahtar Kelimeler: Çevrimiçi Alı̧̧veriş, Sepeti Terk Etme Oranı, Ölçek

Jel Kodları: M30, M31

\begin{abstract}
As it is known, the share of online shopping as an alternative to traditional shopping is increasing day by day. In traditional shopping, it is rare for customers to leave the products they filled in a shopping cart without buying, whereas in online shopping, four out of every five shopping baskets are abandoned. Researching and reducing the reasons for this is an important issue for both academics and businesses. This study aimed to adapt the "Shopping Cart Abandonment Rate Scale" developed by Kukar-Kinney and Close (2010) into Turkish. Analyzes were made on three different samples with a simple random sample and voluntary participants. The sample of the research consists of individuals who shop online in Turkey. Reliability analysis, frequency analysis, KFA (Exploratory Factor Analysis) and DFA (Confirmatory Factor Analysis) were used. As a result of the analysis, a scale with five factors and 17 items was obtained. The use of this scale obtained in research is considered to benefit the gap in the literature.
\end{abstract}

Keywords: Online Shopping, Shopping Cart Abandonment Rate, Scale

Jel Codes: M30, M31
Atıf/Citation: Çavuş Genç, E., \& Karaduman, İ., \& Özkan, A., Çevrimiçi alışveriște sepeti terk etme ölçeğinin Türkçeye uyarlanması, bmij (2021) 9 (3): 1156-1172, doi: https://doi.org/10.15295/bmij.v9i3.1847
(C) 2021 The Author(s).

Bu makale, araştırma ve yayın etiğine uygun hazırlanmış ve iThenticate ile intihal taramasından geçirilmiştir. This article was prepared in line with research and publication ethics and scanned for plagiarism by using iThenticate. 


\section{Extended Abstract}

\section{Adaptation of shopping cart abandonment scale in online shopping to Turkish}

\section{Literature}

\section{Research subject}

Today business uses technology most intensely in their activities and provide new opportunities to these customers, for last quarter-century online shopping increase in its importance day by day. It would be correct to say that especially in the COVID19 pandemic experienced for more than a year, customers become distant from traditional store shopping, and therefore this increase has gained a very high acceleration. While online shoppers added products in the shopping carts to keep track of the products they like and prices of these products, it was understood that they gave up purchasing products in their shopping carts with additional costs such as security concerns, entertainment purposes, lower price expectation, shipping costs. In order to determine these reasons, the determinants of shopping cart abandonment should be examined in detail.

\section{Research purpose and importance}

This study aimed to adapt the "Shopping Cart Abandonment Rate Scale" developed by Kukar-Kinney and Close (2010) to Turkish. Unfortunately, there are no measurement sources to identify shopping cart abandonment factors previously adapted to Turkish.

\section{Contribution of the article to the literature}

Although the scale is used by many researchers abroad, there has not been any study conducted in our country to adapt this scale to Turkish culture. Therefore, the Shopping Cart Abandonment Rate Scale is adapted to the Turkish language and culture that contributes to the literature in this study.

\section{Design and method}

\section{Research type}

The study is a quantitative method, and the data were collected by questionnaire.

\section{Research problems}

Although the scale is used by many researchers abroad, there has not been any study conducted in our country to adapt this scale to Turkish culture.

\section{Data collection method}

Shopping Cart Abandonment Scale initially consists of 19 items and seven factors. In this context, the meaning integrity of the Turkish translations of the scale, which included 19 items, was reviewed in the research. The adaptation of the Shopping Cart Abandonment Scale was considered according to the adaptation method proposed by Brislin (1980). This method is a 5-step method. In the first stage, the scale in the source language is translated into the target language to be used. In the second stage, the scale translated into the target language is evaluated. In the third stage, the scale is checked by retranslating into the source language from which it was taken. In the fourth stage, with the retranslation into the source language, the fifth stage, the expert evaluation stage, is passed.

\section{Quantitative/qualitative analysis}

Exploratory factor analysis (EFA) and confirmatory factor analysis (CFA) were performed.

\section{Findings and discussion}

\section{Findings as a result of analysis}

It is thought that the Shopping Cart Abandonment Scale will be functional both academically and in the sector so that businesses can plan their future and take precautions by investigating the reasons for consumers abandoning the online shopping cart. The scale initially consists of 19 items and seven factors. The data obtained from 425 voluntary employees operating in different service sectors were analyzed. Unlike the original, a 5-factor structure explaining $63,39 \%$ of the total variance was obtained.

\section{Conclusion, recommendation and limitations}

\section{Results of the article}

In this study, the online shopping cart abandonment scale developed by Kukar-Kinney and Close (2010) was adapted to Turkish. Therefore, the validity and reliability of this scale were tested. Furthermore, the factor structure of the shopping cart abandonment scale was examined. As a result, the scale consisting of 5 factors and 17 items was developed. To determine the construct validity of the shopping cart abandonment scale, exploratory and confirmatory factor analyses were performed. Since no scale is currently adapted to Turkish to measure abandoning the shopping cart, it is thought that this scale, whose validity and reliability has been ensured, will shed light on new studies.

\section{Suggestions based on results}

This scale, which was developed by Kukar-Kinney and Close (2010) and applied to consumers living in the United States, was applied by us in the sample group of 425 people living in Turkey. By applying the same scale in other countries, the reasons for consumers to abandon the online shopping cart can be investigated, and the cross-cultural differences of different consumers in distinct countries can be examined. In addition, by examining the factors that determine shopping cart abandonment with different variables in the field of marketing; Studies on all the issues that are abandoning the shopping cart effect and are related to are highly valued in terms of providing and expanding the necessary literature. Finally, the reasons for consumers to abandon the shopping cart for a particular product type and the reasons for abandoning the shopping cart particular to the service sector can be examined.

\section{Limitations of the article}

The study's limitations can be considered to reach a limited number of people evaluated is 425 . 


\section{Giriş}

Bugün işletmeler tüm faaliyetlerinde teknolojiyi en yoğun şekilde kullanmakta ve bu da müşterilere yeni olanaklar sunmaktadır. Son çeyrek yüzyıldır çevrimiçi alışveriş her geçen gün önemini artırmaktadır. Özellikle bir yılı aşkın süredir yaşanan COVID-19 pandemisinde tüketicilerin geleneksel mağazalı alışverişten uzaklaştığını ve bu nedenle de bu artışın oldukça yüksek bir ivme kazandığını söylemek doğru olur.

Geleneksel alışverişte, diğer bir deyişle mağazalı perakendecilikte müşteriler mağaza içerisinde dolaşırlarken satın almak istedikleri ürünleri alı̧̧veriş arabalarına ya da alışveriş sepetlerine koymakta ve satın alacağı tüm ürünleri ekledikten sonra kasaya giderek ödeme yapmaktadır. Bu süreçte müşterilerin doldurdukları sepeti ya da alışveriş arabasını ortada bırakarak alışverişten vazgeçmeleri ve mağazayı terk etmelerine, olağanüstü durumlar dışında pek rastlanılmaz. Sıklıkla görülen bir davranış tüketicinin satın almaktan vazgeçtiği bazı ürünleri raflara geri bırakması şeklindedir ancak bu ürünlerin tamamını satın almaktan vazgeçme şeklinde gerçekleşmez.

Çevrimiçi perakendecilikte ise bu durum bambaşka bir hal almaktadır. Müşteriler alışveriş sepetlerine çeşitli ürünler eklemektedir ancak bu ürünleri satın almaksızın çevrimiçi satış yapan perakendeci mağazanın web sitesini ya da mobil uygulamasını terk etmektedirler. Çevrimiçi perakende sektörü yöneticilerinin uzun süredir zihinlerini meşgul eden bu durum özellikle son ylllarda akademisyenler tarafından da ilgi görmüştür.

Bu çalışmanın literatür araştırmasının ilk bölümünde de müşterilerin çevrimiçi alışverişte sepeti terk etmelerinin nedenlerini ortaya koymaya ve çözüm önerileri sunmaya yönelik olarak yapılmış çalışmalar incelenmiştir. Çalışmanın amacı henüz Türkçede yer almayan Sepeti Terk Etme ölçeğini Türkçeye uyarlamak olarak belirlenmiştir. Bu nedenle 2010 yılında Kukar-Kinley ve Close tarafından geliştirilmiş olan ve literatürde söz konusu tarihten sonra yapılan çalışmalarda sıkça atıf alan ve kullanılan ölçek çalışmanın ikinci bölümünde açılanan yöntem izlenerek Türkçeye uyarlanmıştır.

Çalışmanın üçüncü bölümünde ölçek uyarlaması ile ilgili yöntem takip edilerek elde edilen bulgulara yer verilmiştir. Sonuç, kısıtlar ve önerilere yer verilen son bölümde ise bundan sonra ölçek uyarlama çalışması yürütecek olan akademisyenlere yönelik önerilerde bulunulmuştur.

\section{Literatür araştırması}

\section{Çevrimiçi alışverişte sepeti terk etme davranışı}

Bugünün işletmeleri sadece üretimle sınırlı olmamak üzere tüm faaliyetlerinde teknolojik değişimle sürekli iç içe hareket etmektedir. Teknolojik gelişmelere ayak uydurmak bugün yeterli gelmemekte, değişimi yaratma ve öncü olma gereksinimi her geçen gün artmaktadır. Akkaya, Kayalıdere, Aktaş ve Karğın (2020) rekabet avantajından en üst düzeyde yararlanabilmek için de bunun bir gereksinim olduğundan söz etmektedir. Teknolojinin işletmeler açısından neredeyse bir zorunluluk haline getirdiği bir gelişme de geleneksel dağıtım ve satış kanallarının artık rekabetçi üstünlüğü sağlama ve sürdürmede yeterli gelmemesidir. Hem geleneksel hem de çevrimiçi kanallardan müşteriye ulaşmak bugünün en önemli gereksinimlerinden biri olarak ön plana çıkmaktadır.

2019 yılında 16-74 yaş grubunda internet kullanan bireylerin oranı \%73,3 iken bu oran 2020 yılı için \%79,0'a olarak açıklanmış olup \%7,78'lik bir artışın olduğu gözlemlenmektedir (Tuik, 2020). Verilere göre 2019 yılında bu oranı \%69,57 olarak açılanırken; 2020 yılı için bu oranın \%88,05'e yükseldiği görülmektedir (Statistica, 2020).

Geleneksel alışverişte müşterilerin alışveriş arabalarının ya da sepetlerinin içerisine doldurdukları ürünleri almaktan vazgeçerek bırakıp gitmelerine ender olarak rastlansa da, bu pek de beklenen bir durum değildir. Ancak çevrimiçi alışverişte müşteriler alışveriş sepetine ekledikleri ürünleri çeşitli nedenlerle terk ederek satın almadan çıkış yapabilmektedir. Kodali, Hult, Evans ve McGowan (2010) tarafından yapılan araştırmaya göre, çevrimiçi alışveriş yapanların \% 88 'i, alışverişi tamamlamadan alışveriş sepetini terk etmektedir.

Geleneksel alışverişte alışveriş sepetleri araştırmacıların ilgisini çeken bir konu oluşturmuş ve konuda çok sayıda araştırma yapılmıştır. Bugün hala geleneksel alışveriş sepetine yönelik çalışmalar devam etmektedir. Örneğin Wahab ve Ham (2021) tarafından yapılan çalışma geleneksel alışveriş sepetini RFID etiketiyle destekleyerek daha akıllı bir alışveriş sepeti oluşturmayı hedeflemektedir. Sektör uygulamalarında da benzer çalışmaların sonuçlarının sonuçlarını gözlemlemek olanaklıdır. Örneğin Metro Grossmarket ödeme sürecini ortadan kaldıran, kasaya uğramadan çıkış yapmayı olanaklı hale getiren alışveriş sepetlerini 2020 yilında devreye sokmuştur (Ntv, 2020). 
Çevrimiçi alışverişin ortaya çıkmasından bu yana alışveriş sepeti konusunda birçok araştırma yapılmıştır. Oliver ve Shor (2003) tarafından yapılmış çalışma özünde çevrimiçi indirim kodlarından tüketiciler tarafından duyulan memnuniyet ve memnuniyetsizliği ortaya koymak üzerinedir. Bu çalışmanın ilginç bir sonucu ödeme aşamasında müşterilerin önüne gelen indirim kodunu girme uyarısının alışveriş sepetini terk etmeye neden olan bir etken olduğudur.

Cho, Kang ve Cheon (2006) tarafından yapılan çalışmada çevrimiçi alışverişte duyulan tereddüt incelenmiş, bu tereddüte ve sonucunda satın almayı ertelemeye ve vazgeçmeye neden olan faktörler ortaya konmuştur. Yapılan literatür taramasında elde edilen bulgular ışı̆̆ında doğrudan alışveriş sepetini terk etme konusunu ele alan ve bu konuda bir ölçek oluşturan yapılmış en eski çalışma olarak Kukar-Kinney ve Close (2007) tarafından yapılan araştırmaya rastlanmıştır. Bunun öncesinde konu genellikle perakendecilik sektörünün bir sorunu olarak akademik alanın dışında tartışılmıştır. KukarKinney ve Close (2007) çalışmalarında çevrimiçi alışveriş sepetinin terk edilmesinin temel faktörlerini tespit etmişler ve bu satın almaktan vazgeçmeye dönük davranışın bilişsel ve davranışsal nedenlerini ortaya koymuşlardır ve tüketicilerin çevrimiçi arama, değerlendirmesini ve değerlendirmesine etki eden faktörlerin, alışveriş sepetinin terk edilmesinde satın alma kararı aşamasındaki faktörlerden daha yüksek bir etkiye sahip olduğu sonucuna erişmişlerdir.

Moore ve Mathews (2008) çalışmalarında alışveriş sepetini terk etme olgusunu bir sendrom olarak ele almışlardır. Araştırmalarında, kişisel ve kişilerarası çatışmaların, mobil alışveriş sırasında tüketicilerin duygularını rahatsız ettiği, bunun sonucunda mobil alışveriş sepetinin terk edilmesiyle sonuçlandığı ve bunun sonucunda duygusal olarak kararsız tüketicilerin ürünleri alışveriş sepetine koyduktan sonra ödeme aşamasında tereddüt etme eğiliminde oldukları sonucuna erişmişlerdir.

Biliş-etki-davranış (CAB) paradigmasını temel alan ve Huang, Goo, Nam ve Yoo (2008) tarafından yapılan çalışma, tüketicilerin alışveriş için mobil kanalları kullanmaktan neden tereddüt ettiklerini ve dolayısıyla mobil alışveriş sepetlerini terk ediş nedenlerini açıklayan kavramsal bir çerçeve sunmayı amaçlamıştır.

Rajamma, Paswan ve Hossain (2009) çalışmalarının sonucunda algılanan işlem rahatsızlığının, alışveriş sepetinin terk edilmesinin başlıca öngörücüsü olduğunu ortaya koymuştur. Diğer yordayıcılar ise, algılanan risk ve algılanan bekleme süresidir. Çalışmada, algılanan işlem rahatsızlığı, algılanan risk ve alışveriş sepetini terk etme eğilimi arasında pozitif ilişki bulunmuş ve alışveriş sepetini terk etme eğiliminin bekleme süresi algısı ile olumsuz yönde ilişkili olduğu görülmüştür.

Yine Close ve Kukar-Kinney (2010) tarafından yürütülen bir diğer çalışmada mevcut satın alma niyetlerinin ötesinde, tüketicilerin alışveriş sepetlerine çeşitli nedenlerle ürün yerleştirdikleri ve bu nedenlerin çevrimiçi fiyat promosyonlarını güvence altına almak, belirli ürünler hakkında daha fazla bilgi edinmek, alışveriş ürünlerini düzenlemek ve eğlence olduğu açıklanmıştır.

Egeln ve Joseph (2012) çalışmalarında sepeti terk etme nedeni ile algılanan risk ve algılanan sahiplik arasındaki ilişkiyi incelemişler, algılanan riskin sepeti terk etme oranını artırıcı yönde etkisi olurken, algılanan sahipliğin satın alma işlemini tamamlamaya yönlendirdiği sonucuna ulaşmışlardır.

Alışveriş sepetini terk etme nedenlerini ortaya koymaya yönelik çalışmalarında Xu ve Huang (2015) alışveriş sepetinin terk edilmesinin, sepet içindeki ürünlerin organizasyonu ve araştırılmasının yanı sıra harici web sitelerine kıyasla doğrudan ve olumlu olarak etkilendiği ve ödeme niyetinden doğrudan ve olumsuz olarak etkilendiği sonucuna varmışlardır.

Song (2019) tarafından yapılan çalışmada alışveriş sepeti terk nedenleri ürün kategorisi bazında incelenmiştir. Araştırmanın sonuçları, alışveriş faaliyetlerine yönelik motivasyonlardan müzakere, çevrimdışı fiziksel inceleme ve hedonik alı̧veriş değerinin alışveriş sepetini terk etme üzerinde önemli etkilere sahip olduğunu göstermektedir.

Tang ve Lin (2019) çalışmalarında tüketiciden tüketiciye (C2C) çevrimiçi alışverişte belirsizliği azaltmanın sepeti terk etme oranı üzerindeki etkisini incelemişlerdir. Araştırmalarının sonuçları hem satıcı ile ilgili belirsizliklerin hem de ürün ile ilgili belirsizliklerin tüketicinin çevrimiçi alışveriş sepetini terk etme oranını artırdığı yönünde olmuştur.

Tüketicinin zihin setini temel alan bir bakış açısıyla yaptıkları çalışmada Rubin, Martins, Ilyuk ve Hildebrand (2020) çevrimiçi alışveriş yaparken soyut (somut aksine) bir zihniyete sahip olan tüketicilerin, alışveriş sepetlerine ekledikleri ürünleri daha önemli olarak derecelendirdiğini, satın alma olasılıklarının daha yüksek olduğunu ve dolayısıyla alışveriş sepetinin terk oranının azaldığı sonucuna varmışlardır. 
Zhao, Wang ve Jiang (2020) alışveriş sepetine önceden belirlenmiş bir sınırın üzerinde ürün eklendiğinde belirecek ve satın alma ya da sepeti boşaltmayı önerecek bir pop-up mesajının sepeti terk etme üzerindeki etkisini incelemiştir. Ayrıca çalışmalarında bu mesajın tüketici üzerinde yaratacağı kıtlık etkisi ile satın almaya yönlendirebileceğinin de üzerinde durulmuştur.

Kapoor ve Vij (2021) çalışmalarında sepeti terk etme kavramıyla ödemeyi terk etmeyi iki ayrı kavram halinde değerlendirmiş, ödeme aşamasında müşterinin işlemden çıkışının ayrıca incelenmesi gereken bir fenomen olduğu iddiasını ortaya koymuşlardır. Araştırmalarının sonucunda, alışveriş sepetinin terk edilmesinin, kanallar arası fiyat eşitsizliği, ücretsiz gönderim, derecelendirme ve incelemeden platformun estetik tasarımına kadar birçok değişkenin bir sonucu olduğunu, ödeme işleminin terk edilmesinin ise, nakliye politikası ve hesap yorgunluğunun bir sonucu olduğunu ortaya koymuşlardır.

Tüketiciler çevrimiçi satın almaya hazırlanırken satın almadan vazgeçmeyi tetikleyecek bir dizi engelleyiciyle karşılaşarak süreci iptal edebilmektedir. Geleneksel yöntemde bu engelleyiciler sosyal etkiler, ürün eksikliği (bulunabilirlik), yüksek fiyat, finansal durum veya zaman baskısı iken çevrimiçi yöntemde ise çevrimiçi indirim kodlarının sorulma zamanı (Oliver ve Shor, 2003) kişisel ve kişiler arası çatışmalar (Moore ve Mathews, 2008), algılanan risk (Rajamma vd., 2009), fiziki bir mağazada satın alma kararı eğlence amacı sepeti bir araştırma ve organizasyon aracı olarak kullanma, indirimli fiyat bekleme, siparişin maliyeti hakkında endişe (kargo ücreti, vb.), gizlilik/güvenlik endişeleri (Close ve KukarKinney, 2010), kanallar arası fiyat eşitsizliği, ücretsiz gönderim, derecelendirme ve incelemeden platformun estetik tasarımı (Kapoor ve Vij, 2021), satıcı ve ürüne yönelik belirsizlik (Tang ve Lin, 2019), çevrimdışı fiziksel inceleme ve hedonik alışveriş değeri (Song, 2019), tüketicinin somut bir zihin setine sahip olması (Rubin vd., 2020) ve diğer birçok faktör olabilmektedir.

Genel olarak çevrimiçi alışveriş yapan tüketiciler satın alma sürecinde bir gereksinimlerini ortaya koymakta, bu gereksinimi karşılamak üzere alternatifleri belirlemek üzere araştırmaya başlamakta, alternatifleri değerlendirmekte ve sepetine eklediği ürünü satın alıp almamaya karar vermektedir. Burada yukarıda sayılan nedenlerle sepetindeki ürünleri satın almamaya karar veren tüketiciler olabileceği gibi sepetine eklediği ürünleri satın alma niyetine hiç sahip olmamış tüketiciler de bulunmaktadır. Bunlar da genel olarak bilgi toplama, karşılaştırma yapma gibi faydacı amaçlara sahip olabilecekleri gibi, hedonik nedenlerle de bunu yapabilmektedirler.

\section{Çevrimiçi alışverişte sepeti terk etme davranışı}

Birçok çalışmada araştırmacılar, daha önceden başka araştırmacılar tarafından geliştirilmiş ve kullanılmış olan ölçekleri kullanmayı tercih etmekte kullandıkları ölçekler üzerinde bazı değişiklikler yapabilmektedirler (Heggestad, Scheaf, Banks, Monroe Hausfeld, Tonidandel, ve Williams, 2019). Ancak bir ölçeğin bir başka dilden tercüme edilmesi ve uyarlanmasında belli kurallara uymak ve belli bir yöntemi takip etmek gerekmektedir.

Araştırmalarda kullanılan çeşitli ölçeklerin Türkçeye uyarlanmasına yönelik çalışmalar yapılmıştır. Buna örnek olarak değerlendirme tercihleri ölçeğinin uyarlanması (Gülbahar ve Büyüköztürk, 2008), algılanan stres ölçeğinin uyarlanması (Eskin, Harlak, Demirkıran ve Dereboy, 2013), ilköğretim birinci kademede eğitimde motivasyon ölçeğinin uyarlanması (Kara, 2008), örgütsel iklim ölçeğinin uyarlanması (Y1lmaz ve Altınkurt, 2013) verilebilir.

Bu çalışmada Kukar-Kinney ve Close (2010) tarafından geliştirilen Sepeti Terk Etme ölçeği Türkçeye uyarlanmıştır. Çevrimiçi perakendecilikte pazarlama performansını ölçmek için kullanılan bir ölçek olan sepeti terk etme oranı, bu firmalara çevrimiçi alışverişlerini tamamlamayan ve alışveriş sepetlerini satın almadan bırakan müşterileri anlama fırsatı vermektedir. Birçok pazarlama araştırması sonucu, alışveriş kartının terk edilmesinin ana nedenlerinin yüksek gönderim maliyetlerinden (kargo, kurye vb.) web sitesi sorunlarına (güven, kullanışlılık vb.) kadar değiştiğini göstermektedir.

Sepeti terk etme ölçeği "The determinants of consumers' online shopping cart abandonment" adlı çalışmada kullanılmıştır. Sözkonusu çalışmada, sepeti terk etme davranışının arkasındaki itici güçleri anlama ve bunları önlemek için nelerin yapılması gerektiğini ortaya koyarak çevrimiçi satış sektörüne yardımcı olmayı amaçlayan çalışmada araştırmacılar tüketicinin davranışını anlayabilmek için "tüketicinin satın almama" davranışını ele almış olup çevrimiçi alışveriş sepetinin terk edilme sürecini ise tüketicinin sepete ürün yerleştirip satın alma işlemini yapmadan oturumu kapatması olarak tanımlamıştır. Çalışmada ayrıca çevrimiçi sitelerde müşterilerin ürün ile ilgili ilgi alanlarının neler olduğu ve daha iyi tüketici dostu sitelerin nasıl olması gerektiği anlatılmıştır. 


\section{Araştırma yöntemi}

Çalışmanın amacı, çevrimiçi alışveriş yapan bireylerin sepeti terk etme oranının belirleyici faktörlerin keşfedilmesi ve bu oluşturulan ölçeğin literatürde araştırmalara yardımcı olmasıdır. Özellikle pandemi dönemi ile büyük bir artış yaşanan çevrimiçi alışveriş oranı da dikkate alınarak geliştirilen Sepeti Terk Etmeyi Belirleyen Faktörler Ölçeği' nin araştırma boşluklarında faydalanılabilecek bir kaynak niteliği taşıdığını söylemek mümkündür. Bu değişim durumu tüketici eğilimlerine ve satın alma davranışlarına yön verebilmektedir. Ölçeğin, Türk kültürüne uyarlanması kapsamında yapılan herhangi bir çalışmaya rastlanılmamıştır. Bu çalışmada özellikle çevrimiçi alışveriş yapan tüketicilerin sepeti terk etme oranını belirleyen faktörler incelenerek; bu ölçeğin geçerlilik ve güvenilirliğine ilişkin bulgularının bir defa daha gözden geçirilerek Türkçeye uyarlanması hedeflenmektedir.

Sepeti Terk Etme Ölçeği orijinalde 19 madde ve 7 faktörden oluşmaktadır. Bu kapsamda, yapılan araştırmada öncelikle 19 maddenin yer aldığı ölçeğin Türkçe çevirilerindeki anlam bütünlügüu gözden geçirilmiştir. Sepeti Terk Etme Ölçeğinin uyarlaması için Brislin (1980) tarafından önerilen uyarlama göz önüne alınmıştır. Bu yöntem 5 aşamalı bir yöntemdir. Birinci aşamada kaynak dildeki ölçek kullanılacak hedef dile çevrilmektedir. İkinci aşamada hedef dile çevrilen ölçeğin değerlendirilmesi yapılmaktadır. Üçüncü aşamada ölçeğin alındığı kaynak dile tekrar çevirisi yapılarak kontrol edilmektedir. Dördüncü aşamada ise kaynak dile yapılan tekrar çeviri ile beşinci aşama olan alanında uzman değerlendirme aşamasına geçilmektedir.

Kaynak dil olan İngilizceden Türkçeye çeviri için alanında uzman ana dili Türkçe olan 3 akademisyenden yardım alınmıştır. Her 3 akademisyende ileri seviyede İngilizce diline hakimdir. Birinci akademisyenin daha öncesinde defalarca Türkçeye ölçek uyarlama ve geliştirme deneyimi bulunmaktadır ayrıca yönetim ve organizasyon alanında doktora derecesine sahiptir ve öğretim üyesi olarak görev yapmaktadır. İkinci akademisyen Amerika' daki bir üniversitede mühendislik bölümünde doktora derecesine sahip öğretim üyesi olarak görev yapmaktadır. Diğer akademisyen ise yabancı dil yüksekokullarında görev yapmaktadır. Ölçeğin çevirisi üç ayrı akademisyen tarafından, birbirinden bağımsız olarak yapılmışır. Yapılan Türkçe çevirilerin değerlendirilmesi pazarlama alanında tecrübesi olan dört akademisyen tarafından yapılmışıı. Çeviriler ayrı ayrı okunarak, her bir maddeyi anlaşılırlık, Türkçeye uygunluk, kullanılan kelimelerin doğruluğu ve açılığı yönlerinden değerlendirmeler yapılmış ve üzerinde uzlaşılan çeviriler kullanılarak anket formu oluşturulmuştur. Ortaya çıkan ölçek daha sonra alanında uzman, doktora derecesine sahip, bugüne kadar ölçek uyarlama ve ölçek geliştirme çalışmaları yapan bu çalışmanın araştırmacılarından olan bir akademisyen tarafından İngilizceden Türkçeye çevrilerek dil yapısı, kullanılan kelimelerin uygunluğu ve güncelliği yönlerinden kontrol edilmiş ve orijinal anketle örtüşmesine bakılmıştır. Bu son değerlendirme neticesinde ölçeğin Türkçe çevirisinin hem biçimsel hem de içerik olarak uygun olduğuna ve araştırmada kullanılabileceğine karar vermişlerdir. Bu karar sonucunda ölçeğin uyarlamasının yapılması için üç adım sırasıyla takip edilmiştir:

- Birinci adımda pilot uygulama ile dil ve kapsam geçerlik analizi yapılmıştır.

- İkinci adımda yeni bir örneklem ile ölçeği oluşturan maddeler için güvenilirlik incelemeleri ve keşfedici faktör analizi (KFA) ve doğrulayıcı faktör Analizi (DFA) yapılmıştır.

- Üçüncü adımda ise, ölçeğin son hali yeni bir örnekleme uygulanarak (tekrar test), yapısal geçerlilik ve güvenilirlik incelemeleri tekrarlanarak, faktör yapısının doğrulanması ve faktör yapı geçerliğini belirlemek için KFA'dan elde edilen madde-faktör yapısı doğrulayıcı faktör analizi (DFA) ile tekrar test edilmiştir.

Analizleri gerçekleştirmek için SPSS ve AMOS programlarından yararlanılmıştır. İlgili alan yazın incelendiğinde ölçek geliştirme ve uyarlama çalışmalarında optimal örneklem büyüklükleri ile ilgili farklı araştırmacıların farklı görüşleri bulunduğu görülmektedir. Bu araştırmada Gorsuch (1974), Kline (1979) örneklemlerin en az 100 olmalı önerisi benimsenmiş (Akt. Çolakoğlu ve Büyükekşi, 2014: 59), bundan dolayı her bir adımda en az 100 ve üzeri üç örneklem üzerinde araştırma yapılmıştır. İzleyen bölümlerde söz konusu üç örnekleme ait betimleyici istatistikler ve gerçekleştirilen istatistiksel analizlere ilişkin bulgulara yer verilmiştir. Analizler basit tesadüfi örneklem ile gönüllü katılımcıların olduğu üç farklı örneklem üzerinde yapılmıştır. Araştırmanın örneklemi, Türkiye'deki çevrimiçi alışveriş yapan bireylerden oluşmaktadır. Bu çalışmanın verileri 2020 yılı Ocak - Mart ayları arasında toplanmıştır. Ankete katılan 447 kişiden 22'sinin "Çevrimiçi (Online) alışveriş yapıyor musunuz?" sorusuna "Hayır" cevabı vermiş olmalarına istinaden bu kişiler araştırmanın örneklemine uymadığ için yanıtları analiz dışı bırakılmıştır. 


\section{Araştırmanın bulguları}

\section{Birinci örnekleme ilişkin bulgular}

İlk aşamada, 19 maddelik Sepeti Terk Etmeyi Belirleyen Faktörler Ölçeği çevrimiçi alışveriş yapan 105 katılımcıya pilot çalışma olarak uygulanmıştır. Bu örneklem ile yapılan çalışmada; ölçeği oluşturan maddelerin Türkçe dilbilgisine uygunluğu, ölçekte yer alan bazı maddelerin anlaşılmasında karşılaşılabilecek problemlerin giderilmesi ve ölçek maddelerinin düzenlenmesi hedeflenmiştir. Bu gruptaki çalışanların yaşlarına bakıldığında katılımcıların \% 8,6'sı 18-25 yaş arası, \%31,4'u 26-33, \%21'i $34-41, \% 26,7^{\prime}$ si 42-49, \%12,4'ünün ise 50 yaş ve üzeri olduğu görülmektedir. Katılımcıların cinsiyetine bakıldığından \%69,5'i kadın ve \%30,5'i ise erkektir. Katılımcıların \%56,2'si evli iken \%43,8'i bekârdır. Katılımcların eğitim düzeyleri incelendiğinde $\% 3,8^{\prime} i$ orta öğretim, $\% 7,6^{\prime}$ sı lise, $\% 12,4^{\prime} \ddot{u}$ ön lisans, $\% 36,2^{\prime}$ si lisans, \%25,7'si yüksek lisans ve \%14,3'ü doktora derecesine sahiptir. "Öğrenci misiniz?" sorusuna katılımcıların \%33,3'ü evet, \%66,7'si ise hayır cevabı vermiştir. "Çalışıyor musunuz?" sorusuna katılımcıların \%88,6'sı evet, \%11,4'ü ise hayır cevabı vermiştir.

Pilot uygulama ile dil ve kapsam geçerliği ile güvenirlik sınaması yapılmıştır. Birinci örneklemden sonra ölçekte bazı düzeltmeler yapılarak 19 sorudan oluşan aynı ölçek ikinci bir örnekleme uygulanmıştır.

\section{İkinci örnekleme ilişkin bulgular}

İkinci örneklem çevrimiçi alışveriş yapan bireyler arasından seçilen 288 kişiden oluşmaktadır. Birinci örneklemin dahil edildiği bu örneklemi tanımlamak adına frekans analizinden yararlanılmıştır. Bu gruptaki çalışanların yaşlarına bakıldığında katılımcıların \%0,7'si 18 yaşın altında, \%10,4'ü 18-25 yaş arası, \%37,2'si $26-33, \% 26,7^{\prime}$ si 34-41, \%16'sı 42-49, \%9'unun 50 ve üzeri yașta olduğu görülmektedir. Katılımcıların cinsiyetine bakıldığından \%70,8'i kadın ve \%29,2'si ise erkektir. Katılımcıların \%51,4'i evli iken \%48,6'sı bekârdır. Katılımcıların eğitim düzeyleri incelendiğinde, \%1,4'ü orta öğretim, \% 8'i lise, $\% 10,8^{\prime} \mathrm{i}$ ön lisans, \%41'i lisans ve \%30,9'u yüksek lisans, \%8'i ise doktora derecesine sahiptir. "Öğrenci misiniz?" sorusuna katılımcıların \%25,7'si evet, \%74,3'ü ise hayır cevabı vermiştir. "Çalışıyor musunuz?" sorusuna katılımcıların \%90,3'u evet, \%9,7'si ise hayır cevabı vermiştir.

Keşfedici faktör analizine geçemeden verilerin Kaiser-Meyer-Olkin (KMO) değerine bakılması gerekmektedir. Bu değerin 0,5'ten büyük olması ve 1'e yakın olması örneklem büyüklüğünün yeterliliği hakkında bilgi vermektedir (Durmuş, Yurtkoru ve Çinko, 2018:80; Büyüköztürk, 2018: 136; Tabak, Kızıloğlu ve Türköz, 2013; Gürbüz ve Şahin, 2018: 319). Diğer yandan faktör analizi yapabilmek için diğer önemli bir koşul ise Barlett'in küresellik testine ilişkin p değerinin 0,05'ten küçük olmasıdır (Karagöz, 2016: 879). İkinci örneklemde elde edilen verilerin faktör analizine uygun olduğunu gösteren Barlett Testi ve Kaiser-Meyer-Olkin testi sonuçları Tablo 1'de verilmiştir.

Tablo 1: KMO ve Bartlett Küresellk Testleri Sonuçları

\begin{tabular}{|l|c|}
\hline Kaiser-Meyer-Olkin (KMO) & 0,714 \\
\hline Bartlett Küresellik Testi & 1776,752 \\
Ki Kare İstatistiği (Anlamlılık) & $(, 000)$ \\
\hline Serbestlik Derecesi & 136 \\
\hline
\end{tabular}

Keşfedici Faktör Analizi (KFA): Keşfedici faktör analizi geliştirilen bir ölçekte gözlenen değişkenleri tanımlayabilmek ve özetlemek amacıyla gerçekleştirilmektedir. $\mathrm{Bu}$ tanımlanan ve özetlenen değişkenler ile üzerinde çalışılabilir ve yönetilebilir seviyede faktörler belirlenebilmektedir. KFA'nın başarılı bir şekilde uygulanabilmesi için KMO değerinin 0,60 ve üzerinde seyretmesi gerekmektedir. Analizde her bir maddenin Eigen Value (öz değerinin) 1'den büyük olması ve faktör yük değerlerinin alt sınır olarak kabul edilen $0.30^{\prime}$ dan büyük olması gerekmektedir. 0,30'un altında kalan veya birden fazla faktörde yer alan maddelerin ölçekten çıkarılması gerekliği ifade edilmektedir (Büyüköztürk, 2018: 134; Gürbüz ve Şahin, 2018: 319). Tablo 1'de yer alan KMO değeri dikkate alındığında bu değerin 0,714 olduğu görülmektedir. Bu değer 0,60 'ın üzerinde olduğu için örneklemin faktör analizi için yeterli olduğu saptanmıştır.

Dolayısıyla Türkçeye uyarlanan Sepeti Terk Etmeyi Etkileyen Faktörler Ölçeği'ndeki faktör yük değeri 0,30 'dan düşük olan 8 . Madde (Alışveriş sepetime ürün seçeneklerini daraltmak ve daha kolay değerlendirebilmek için ürün eklerim.) ve birden fazla faktörde yer alan 9. Madde (Alışveriş sepetini bilgi toplama amaçlı kullanırım.) ölçeğin daha anlamlı olması için ölçekten çıkarılmış ve faktör yapısı yeniden kontrol edilmiştir. KFA sonucunda, 17 maddeden oluşan 5 faktörlü sepeti terk etme oranını belirleyen faktörler ölçeği toplam varyansın \%63,388'ini açıklamaktadır. Bu değerin \%50'yi geçiyor olması faktör analizi için önemli bir kıstas olduğu araştırmacılar tarafından ifade edilmektedir 
(Büyüköztürk, 2018: 135; Gürbüz ve Şahin, 2018: 320). Faktörlerin aç1klanan varyans miktarları birinci faktör için \%23,042, ikinci faktör için \%15,020, üçüncü faktör için \%11,563, dördüncü faktör için $\% 7,564$ ve beşinci faktör için \%6,199 olarak belirlenmiştir. Bu sonuçlar Tablo 2' de verilmiştir.

Tablo 2: Açılanan Toplam Varyans Miktarları

\begin{tabular}{|c|c|c|c|c|c|c|}
\hline \multirow{2}{*}{ Faktör } & \multicolumn{3}{|c|}{ Başlangıç Özdeğerleri } & \multicolumn{2}{c|}{ Faktör Yüklerinin Döndürülmüş Toplamları } \\
\cline { 2 - 7 } & Toplam & Varyans\% & Kümülatif \% & Toplam & Varyans\% & Kümülatif \% \\
\hline 1 & 3,917 & 23,042 & 23,042 & 2,839 & 16,700 & 16,700 \\
\hline 2 & 2,553 & 15,020 & 38,061 & 2,226 & 13,095 & 29,795 \\
\hline 3 & 1,966 & 11,563 & 49,624 & 2,164 & 12,729 & 42,524 \\
\hline 4 & 1,286 & 7,564 & 57,189 & 1,805 & 10,617 & 53,141 \\
\hline 5 & 1,054 & 6,199 & 63,388 & 1,742 & 10,247 & 63,388 \\
\hline
\end{tabular}

Ölçekte yer alan maddelerin faktör dağılımlarını belirlemek için Varimax döndürme analizi yapılmıştır. 8. ve 9. maddenin ölçekten çıkarılmış son haliyle verilere yeniden keşfedici faktör analizi yapılmıştır. Tablo 3'e bakıldığında ölçekte yer alan tüm maddelerin sınır kabul edilen 0,30' dan büyük olduğu görülmektedir. En düşük değerin 0,411; en yüksek değerin ise 0,896 olduğu görülmektedir. Bu değerler doğrultusunda her bir maddenin değerinin yüksek ve birbirleriyle ilişkili olduğu belirlenmektedir.

Tablo 3: Faktör Analizi Sonrası Dönüştürülmüş Madde Bileşenler Matrisi

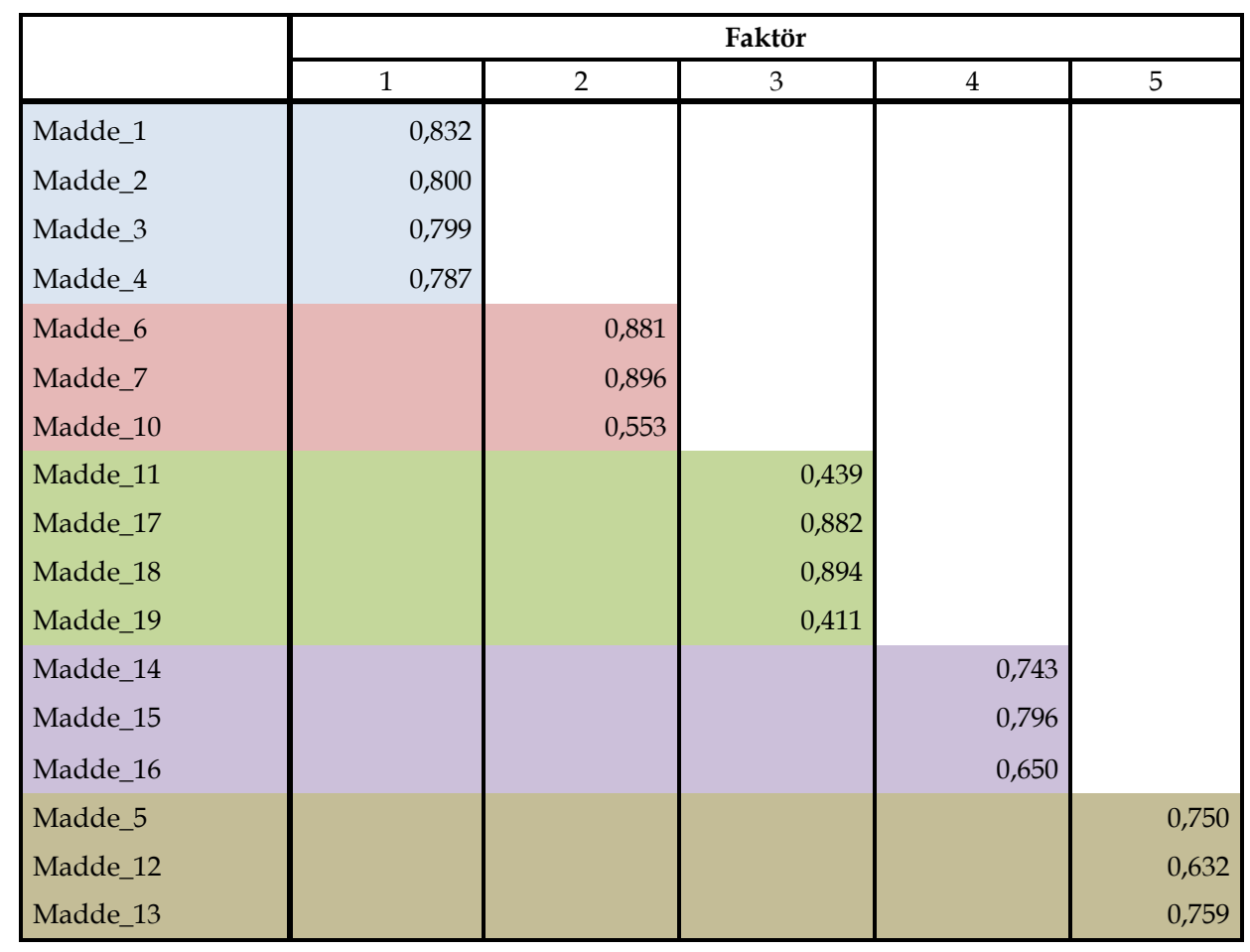

Yapılan analizler sonucunda, Sepeti Terk Etmeyi Etkileyen Faktörler Ölçeği'nin 17 maddeden ve 5 faktörden oluşan bir yapıya sahip olduğu Tablo 3'te görülmüştür. Ölçek için hesaplanan Cronbach's Alpha iç tutarlılık, ortalama ve standart sapma değerleri Tablo 4'te sunulmuştur. Her bir faktörde yer alan maddeler ve her bir alt boyut Tablo 5'te verilmiştir. Cronbach's Alpha değerinin 0,70'ten büyük olması ölçeğin güvenilir olduğunu göstermektedir (Durmuş vd., 2018: 89; Büyüköztürk, 2018: 180; Çelik, 2016: 55). Analiz sonucunda Cronbach's Alfa değerlerinin tüm ölçekte 0,70 sınırından yüksek olduğu izlenmiş, dolayısıyla ölçeğin iç tutarlık katsayısının güvenilir olduğu kabul edilmiştir. 
Tablo 4: Cronbach Alfa, Ortalama, Standart Sapma Değerleri Tablosu

\begin{tabular}{|l|c|c|c|c|c|}
\hline & Madde Sayısı & Cronbach Alfa & Ortalama & Standart Sapma & Min.-Mak. \\
\hline Sepeti Terk Etme Ölçeği & 17 & 0,783 & 3,30 & 0,55 & $1-5$ \\
\hline
\end{tabular}

Tablo 5: Ölçekte Yer Alan Maddeler ve Boyutları

\begin{tabular}{|c|l|c|}
\hline $\begin{array}{c}\text { Boyut } \\
\text { Sırası }\end{array}$ & \multicolumn{1}{|c|}{ Boyut } & $\begin{array}{c}\text { Ölçekteki Madde } \\
\text { Numarası }\end{array}$ \\
\hline 1 & F1- Online Alışveriş Sepetinin Terk Edilmesi & $1,2,3,4$ \\
\hline 2 & $\begin{array}{l}\text { F2- Eğlence Değeri ve Sepeti Bir Araştırma Ve Organizasyon Aracı Olarak } \\
\text { Kullanmak }\end{array}$ & $6,7,10$ \\
\hline 3 & $\begin{array}{l}\text { F3- Fiziki Bir Mağazadan Satın Alma Kararı ve Daha Düşük/İndirimli Bir } \\
\text { Fiyat Bekleme }\end{array}$ & $5,12,13$ \\
\hline 4 & F4- Gizlilik/Güvenlik Endişeleri & $11,17,18,19$ \\
\hline 5 & F5- Siparişin Maliyetleri Hakkında Endişe & $14,15,16$ \\
\hline
\end{tabular}

Doğrulayıcı Faktör Analizi (DFA): Doğrulayıcı faktör analizi, daha önce kullanılan ölçeklerin özgün yapısının toplanan veriler ile doğrulanıp doğrulanmadığını belirlemek amacıyla kullanılmaktadır. Keşfedici faktör analizi ile faktör yapısının belirlenmesinden sonra, doğrulayıcı faktör analizi ile söz konusu ölçeğin yapı geçerliliği belirlenir (Gürbüz ve Şahin, 2018: 317; Özkan, Akkaya ve Özkan, 2020: 3740). DFA'da, ilişkisiz model, tek faktörlü model, birinci seviye DFA ve ikinci seviye DFA olmak üzere dört ölçüm modeli bulunmaktadır (Akkaya ve Tabak, 2018: 192). Çalışmadan elde edilen veriler sonucunda model uyum iyiliği değerlerine göre en uygun model birinci seviye çok faktörlü DFA olduğuna karar verilmiştir.

Birinci seviye çok faktörlü DFA, bir ölçekteki gözlenen değişkenlerin birden fazla faktör altında toplandığı modeldir. Bu modelde gözlenen değişkenlerin ortak varyanslarının birbirine benzerliğine göre aynı faktör altında toplanmaktadır. Aynı faktör altındaki maddeler birbirleriyle ilişkili iken diğer faktörlerde yer alan gözlenen değişkenlerden nispeten bağımsızdır (Gürbüz ve Şahin, 2018: 317). Modifikasyon değerleri yüksek olan ve aynı faktörde yer alma şartıyla bazı maddeler arasında kovaryanslar oluşturularak iyileştirme yapılabilir (Schreiber, Nora, Stage, Barlow ve King, 2006; Karagöz, 2016). Bu modelde uyum iyiliği değerlerini azaltan bazı değişkenler belirlenmiş, artık değerler arasında modifikasyon değerleri yüksek olanlar için yeni kovaryanslar oluşturulmuştur (e3-e4). Bu araştırmada uyum iyiliği değerleri kabul edilebilir seviyede çıan model "birinci düzey çok faktörlü model" Şekil 1'de sunulmuştur $\left(\Delta \chi^{2}=300,928\right.$, sd $=113 \chi^{2} / \mathrm{sd}=2,663, \mathrm{NFI}=0,834, \mathrm{CFI}=0,888, \mathrm{RFI}=0,801$, $\mathrm{IFI}=0,890, \mathrm{TLI}=0,866, \mathrm{RMSEA}=0,076, \mathrm{p}=0,000)$. 


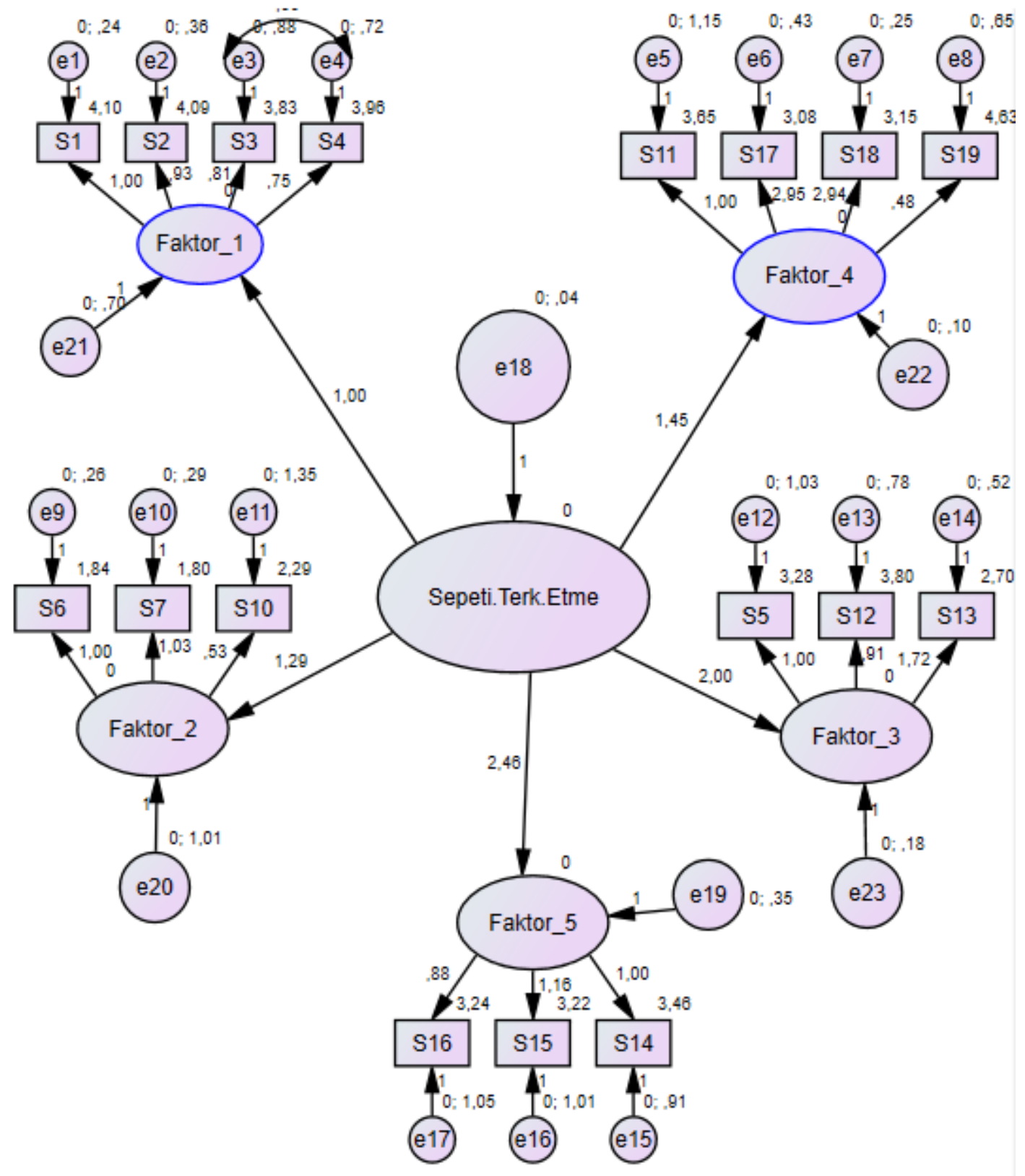

Şekil 1: Birinci Düzey Çok Faktörlü Model

\section{Üçüncü örnekleme ilişkin bulgular}

Son örneklemde daha önce faktör yapısı belirlenmiş Sepeti Terk Etmeyi Belirleyen Faktörler Ölçeği'ne, DFA tekrar yapılmıştır. Bu aşamada toplam elde edilen 425 kişilik örneklem üzerinden analiz yapılmıştır. Bu gruptaki çalışanların yaşlarına bakıldığında katılımcıların \%0,7'si 18 yaşın altında, $\% 22,4^{\prime}$ ü $18-25$ yaş arası, \%33,2'si 26-33, \%24'ü 34-41, \%13,4'ü 42-49, \%6,4'ü 50 ve üzeri yaşta olduğu görülmektedir. Katılımcıların cinsiyetine bakıldığından $\% 75,1^{\prime} i$ kadın ve $\% 24,9^{\prime} u$ ise erkektir. Katılımcıların \%48,7'si evli iken \%51,3'ü bekârdır. Katılımcıların eğitim düzeyleri incelendiğinde, $\% 1,9^{\prime}$ u orta öğretim, \%10,4'ü lise, \%18,1'i ön lisans, \%40,2'si lisans ve \%23,5'i yüksek lisans, \%5,9'u ise doktora derecesine sahiptir. "Öğrenci misiniz?" sorusuna katılımcıların \%35,3'ü evet, \%64,7'si ise hayır cevabı vermiştir. "Çalışıyor musunuz?" sorusuna ise \%68'i evet, \%32'si hayır cevabı vermiştir.

Bu örneklemde orijinaldeki ve bu araştırmanın ikinci örneklem gibi ikinci düzey çok faktörlü modelli doğrulayıcı faktör analizi yapılmıştır. Ölçeğin tamamı Cronbach Alfa değeri 0,783 olarak hesaplanmıştır. Söz konusu güvenirlik değerleri analiz için oldukça yüksektir. Bu modelde de uyum iyiliği değerlerini azaltan bazı değişkenler belirlenmiş, artık değerler arasında modifikasyon değerleri yüksek olanlar için yeni kovaryanslar oluşturulmuştur (e3-e4). Son örneklemden elde edilenler veriler ile yapılan ikinci düzey doğrulayıc faktör analizi sonucunda, elde edilen uyum iyiliği değerleri $\left(\Delta \chi^{2}=\right.$ 362,852, sd= $113 \chi^{2} / \mathrm{sd}=3,211, \mathrm{NFI}=0,854, \mathrm{CFI}=0,893 \mathrm{RFI}=0,824, \mathrm{IFI}=0,894, \mathrm{RMSEA}=0,072$ ve $\mathrm{p}=, 000$ ) olarak bulunmuş ve standartlaştırılmış tahmini değerlerin pozitif olduğu Şekil 2' de gösterilmiştir. 


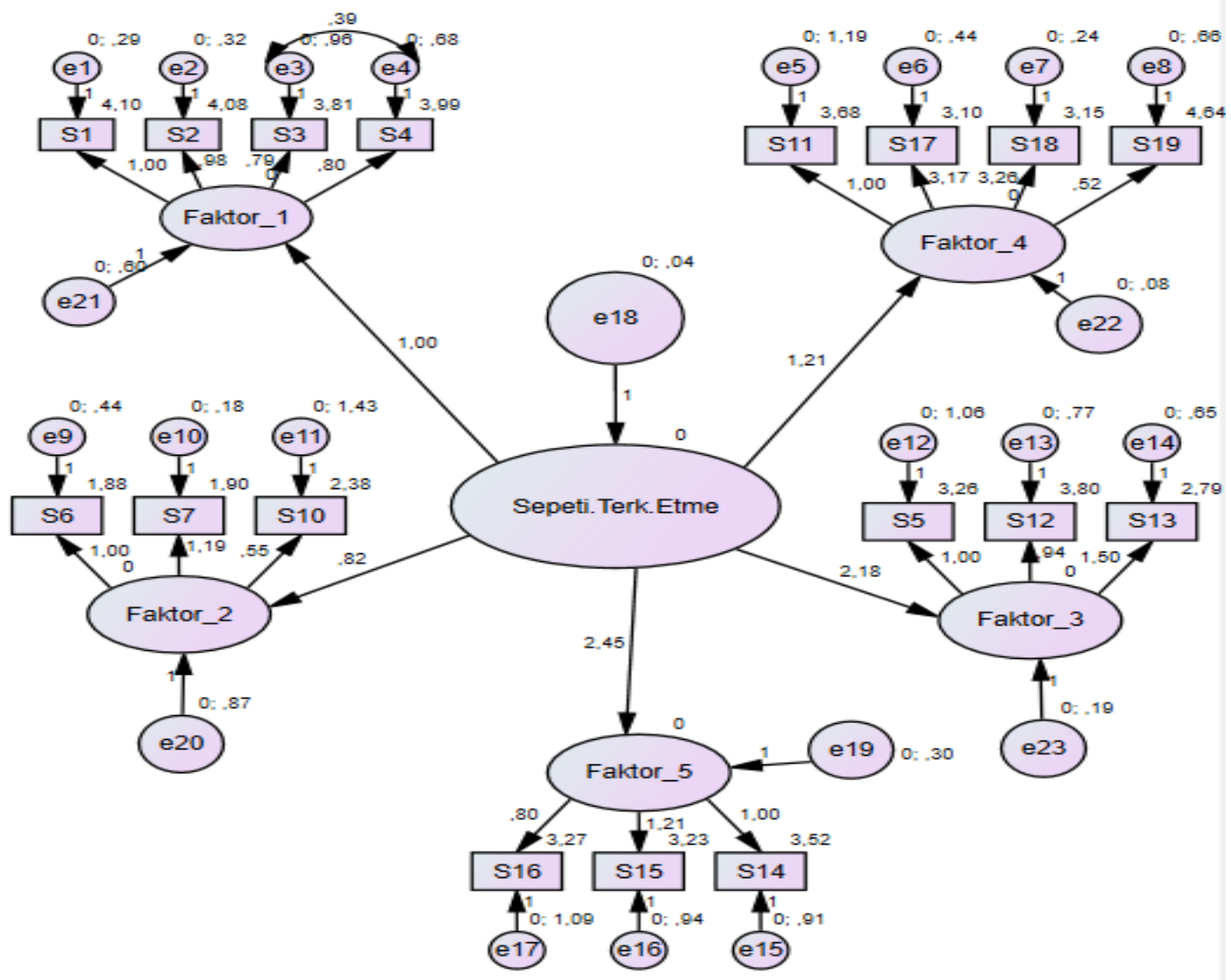

Şekil 2: Doğrulayıcı Faktör Analizi AMOS Diyagramı (Son Örneklem)

Analizde Anti-image korelasyon tablosu incelendiğinde, örneklem yeterliliği ölçümlerinin $0,50^{\prime}$ den büyük olduğu görülmektedir. En düşük değerin 0,597 ile 6. Madde, en yüksek değerin ise 0,850 ile 19. Madde olduğu anlaşılmaktadır. Anti-image tablosu Tablo 6'da sunulmuştur. Faktör ortalamalarına ilişkin bilgi ise Tablo 7'de verildiği gibidir. Faktör ortalamaları incelendiğinde ortalaması en yüksek faktör Faktör 1, ortalaması en düşük faktör ise Faktör 2 olarak tespit edilmiştir.

Tablo 6: Anti-image Korelasyon Tablosu

\begin{tabular}{|c|c|c|c|c|c|c|c|c|c|c|c|c|c|c|c|c|c|}
\hline \multicolumn{18}{|c|}{ Anti-image Korelasyon Tablosu } \\
\hline & S1 & S2 & S3 & S4 & S5 & S6 & S7 & S10 & S11 & S12 & S13 & S14 & S15 & S16 & S17 & S18 & S19 \\
\hline S1 & ,739a & $-0,549$ & - &,- 164 & 007, & -, 062 & ,073 & |-105 & -, & 101,- & -032,- &,- 012 & 056 & 053 & 154, &,- 101 &,- 112 \\
\hline S2 &,- 549 &, $725^{\mathrm{a}}$ &,- 079 & -142 &,- 004 & ,068 &,- 061 & ,083 & ,111 &,- 060 & ,029 & ,015 &,- 030 &,- 261 &,- 085 & ,085 & ,013 \\
\hline S3 &,- 057 &,- 079 & ,746 &,- 537 & ,018 & ,065 &,- 003 &,- 044 & ,038 & 152,- &,- 023 & 111, & 021 & -,080 &,- 034 & , 056 & , 020 \\
\hline S4 & 164 & -142 &,- 537 & $744^{a}$ & - & -,104 & $\mid-, 007$ & $\mid-103$ & -,- 077 & ,098 & 094 &,- 162 & 097, & 005, & 050 & -,075 & - \\
\hline S5 & 007 &,- 004 & ,018 &,- 090 & ,768 &, 025 & ,096 &, 044 &,- 001 &,- 062 &,- 340 &,- 056 &,- 006 & $\mid-, 093$ &,- 043 & ,016 &,- 001 \\
\hline S6 &,- 062 & , 068 & , 065 &,- 104 & ,025 &, $597^{\mathrm{a}}$ &,- 717 & -,042 & 085, & ,071 &,- 041 & 015, &,- 006 &,- 073 &,- 024 &,- 004 & 053 \\
\hline S7 & 073, &,-- 061 &,- 003 &,- 007 & 096 & -,717 & ,603a & - 174 & -154 &,- 001 & $-2,054$ & 018, & 033 &,- 028 & ,074 &,- 062 & 031 \\
\hline S10 & 105,- & 083 & -,044 & -,103 & 044 & -,042 & - 174 & ,847a & -,087 &,- 050 & - 136 &,- 019 &,- 060 & -,028 &,- 094 & 087, & 087, \\
\hline S11 & $\mid-, 038$ & 111, & 038, & -, &,- 001 & 085, & $\mid-, 154$ & $\mid$ &, $813^{a}$ & $\mid-257$ & 027, &,- 075 & -,047 & $|-|, 084$ & - &,- 020 & |010,- \\
\hline S12 & -,101 &,- 060 &,- 152 & 098 &,- 062 & 071 &,- 001 &,- 050 &,- 257 & ,799a & - -267 &,- 071 & ,038 & 034 & ,030 &,- 098 &,- 017 \\
\hline S13 &,- 032 & ,029 &,- 023 & 094 &,- 340 &,- 041 &,- 054 & -,136 & ,027 & -267 & ,788 &,- 015 &,- 029 &,- 038 &,- 033 &,- 090 &,- 015 \\
\hline S14 &,- 012 & 015, & 111, &,- 162 &,- 056 & 015 & 018 & $\mid-, 019$ &,- 075 & -,071 &,- 015 & ,756 &,- 369 &,- 075 &,- 069 & 038 & 014 \\
\hline S15 & 056, &,- 030 & ,021 & 097, &,- 006 &,- 006 & 033 &,- 060 &,- 047 & ,038 &,- 029 &,- 369 &, $751^{a}$ &,- 220 &,- 054 &,- 063 &,- 061 \\
\hline S16 & 053, &,- 261 &,- 080 & 005 &,- 093 &,- 073 &,- 028 & $\mid-, 028$ &,- 084 & ,034 &,- 038 &,- 075 &,- 220 & ,837a & ,044 &,- 081 &,- 019 \\
\hline S17 & 154 &,- 085 &,- 034 & 050 &,- 043 &,- 024 & ,074 &,- 094 &,- 085 & ,030 &,- 033 &,- 069 &,- 054 & ,044 & ,647a &,- 766 &,- 044 \\
\hline S18 &,- 101 & ,085 & ,056 &,- 075 & ,016 &,- 004 &,- 062 & ,087 &,- 020 &,- 098 &,- 090 & ,038 &,- 063 &,- 081 &,- 766 &, $662^{a}$ &,- 077 \\
\hline S19 & -,112 & 013, & 020 &,- 034 &,- 001 & 053 & 031 & 087 &,- 010 & - & -,015 & 014 &,- 061 & $\mid-, 019$ &,- 044 & -,077 & ,850a \\
\hline
\end{tabular}


Tablo 7: Faktör Ortalamaları Tablosu

\begin{tabular}{|l|r|r|r|r|r|r|r|}
\hline \multicolumn{7}{|c|}{ Tanımlayıcı İstatistikler } \\
\hline & Katılımc Sayısı & Faktör Ortalaması & Standart Sapma & Çarpıklı (Skewness) & Basıklı (Kurtosis) \\
\cline { 5 - 9 } & & & & İstatistik & Std. Hata & İstatistik & Std. Hata \\
\hline Faktör 1 & 425 & 3,9935 &, 83876 &,- 895 &, 118 &, 789 &, 236 \\
\hline Faktör 2 & 425 & 2,0533 &, 98935 &, 978 &, 118 &, 415 &, 236 \\
\hline Faktör 3 & 425 & 3,2831 &, 88760 &,- 224 &, 118 &,- 170 &, 236 \\
\hline Faktör 4 & 425 & 3,6429 &, 84797 &,- 288 &, 118 &,- 552 &, 236 \\
\hline Faktör 5 & 425 & 3,3396 &, 94362 &,- 379 &, 118 &,- 047 &, 236 \\
\hline
\end{tabular}

Yapılan bu son işlem sonucunda 5 faktörlü ve 17 maddeli bir ölçek elde edilmiştir. Sepeti Terk Etme Ölçeğinin Türkçeye uyarlanmış faktör yapısı ve bu faktörleri oluşturan maddelerin son hali Ek-1'de, İngilizce dilinde orijinal hali ise Ek-2' de yer almaktadır.

\section{Sonuç ve öneriler}

Bu çalışmada Kukar- Kinney ve Close (2010) tarafından geliştirilen çevrimiçi alışveriş sepeti terk etme ölçeğinin Türkçeye uyarlanması sağlanmış, yapılan analizler ile ölçeğin geçerliliği ve güvenilirliği test edilmiştir. Sepeti terk etme ölçeğinin faktör yapısı incelenerek sonuç olarak 5 faktörlü 17 maddelik ölçek geliştirilmiştir. Faktörler Türkçeye çevrilmiş ölçeğin son halinde "Genel Terk Etme", "Eğlence”, "Fiziki Mağaza Kararı", "Güvenlik" ve "Maliyet" olarak adlandırılmıştır. Faktör ortalamalarının incelendiği analizde en yüksek faktör ortalamasının "Genel Terk Etme" faktöründe, en düşük faktör ortalamasının ise "Eğlence" faktöründe olduğu görülmektedir.

$\mathrm{Bu}$ araştırma için çevrimiçi alışveriş yapan 3 örneklem grubu ayrı ayrı değerlendirilmiştir. Çevrimiçi alışveriş yapan tüketiciler beğendikleri ürünleri ve ürünlerin fiyatlarını takip etmek için sepete ürün eklerken; güvenlik endişesi, eğlence amacı, daha düşük fiyat beklentisi, kargo ücreti gibi ek maliyetlerle sepetindeki ürünleri satın almaktan vazgeçtikleri boyutlarda yer alan ifadelerle desteklenerek araştırılmıştır.

Eğlence amacıyla veya can sıkıntısı ile alışveriş sepetine ürün ekleyen tüketiciler için perakendeciler tüketicilerin sitedeki etkileşimini daha eğlenceli hale getirebilmelidir. Günümüzde bunu sanal gerçeklik uygulamaları ve oyunlarla yapabilmek mümkündür. Ayrıca ürünler hakkında detaylı bilgi verilerek tüketicinin merakı giderilebilir, bu sayede tüketicinin çevrimiçi ürünü satın alması sağlanabilmektedir.

Kargo, KDV ücreti gibi ek maliyet endişesi ile alışveriş sepetini terk eden tüketicilere gelecekte satış yapma fırsatı yakalanmalıdır. Perakendeciler promosyon teklifleri, kargo bedava kampanyaları düzenleyebilir, fiyatı düşen bir ürün için tüketiciye hatırlatma e-postaları gönderebilir. Xie, Teo ve Wan (2006) çalışmasında daha düşük fiyattan ürünü satın almayı bekleyen ve araştıran tüketicileri indirim veya kuponlar ile teşvik ederek ödüllendirilmesi gerektiğini belirtmiştir. Yine çok kanallı pazarlama yöntemleri ile internetten satın alıp mağazadan teslim alma gibi uygulamalarla kargo bedava yapilabilmektedir.

Kukar-Kinney ve Close (2010) tarafından geliştirilen ve Amerika Birleşik Devletleri'nde yaşayan tüketicilere uygulanan bu ölçek, Türkiye'de yaşayan 425 kişilik örneklem grubunda uygulanmıştır. Aynı ölçeğin diğer ülkelerde de uygulanarak, tüketicilerin çevrimiçi alışveriş sepeti terk etme nedenleri araştırılabilir, farklı ülkelerdeki farklı tüketicilerin kültürler arası farklılıkları incelenebilir. Ayrıca sepeti terk etmeyi belirleyen faktörlerin pazarlama alanında farklı değişkenler ile irdelenerek; sepeti terk etmenin etkilediği ve ilişkide olduğu tüm konular ile ilgili yapılan çalışmalar, gerekli literatürün sağlanması ve genişlemesi için büyük önem arz etmektedir. Son olarak tüketicilerin belirli bir ürün türü için alışveriş sepetini terk etme nedenleri üzerinde çalışma yapılabileceği gibi, hizmet sektörüne özel alışveriş sepetini terk etme nedenleri de incelenebilir.

Hali hazırda Türkçe geliştirilmiş veya uyarlanmış sepeti terk etmeyi ölçümlemeye yönelik bir ölçek olmadığı için geçerliliği ve güvenirliği sağlanmış bu ölçeğin yeni araştırmalara 1şık tutacağı düşünülmektedir. 


\section{Hakem Değerlendirmesi / Peer-review:}

Dış bağımsız

Externally peer-reviewed

\section{Çıkar Çatışması / Conflict of interests:}

Yazar(lar) çıkar çatışması bildirmemiştir.

The author(s) has (have) no conflict of interest to declare.

\section{Finansal Destek / Grant Support:}

Yazar(lar) bu çalışma için finansal destek almadığını beyan etmiştir.

The author(s) declared that this study has received no financial support.

\section{Etik Kurul Onayı / Ethics Committee Approval:}

Bu çalışma için etik kurul onayı, İstanbul Aydın Üniversitesi, Sosyal Bilimler Etik Kurulu/Komitesinden 22/12/2020 tarihli 2020/11 sayılı karar ile alınmıştır.

Ethics committee approval was received for this study from Istanbul Aydin University, Social Sciences Ethics Committee on 22/12/2020 and 2020/11 document number.

\section{Yazar Katkıları / Author Contributions:}

Fikir/Kavram/Tasarım - Idea/Concept/ Design: E.Ç.G., Veri Toplama ve/veya İşleme - Data Collection and/or Processing: E.Ç.G., I.K., A.Ö., Analiz ve/veya Yorum - Analysis and/or Interpretation: A.Ö., Kaynak Taraması - Literature Review: İ.K., Makalenin Yazımı - Writing the Article: E.Ç.G., İ.K., A.Ö., Eleştirel İnceleme - Critical Review: E.Ç.G., İ.K., A.Ö., Onay - Approval: E.Ç.G., İ.K., A.Ö.

\section{Kaynakça / References}

Akkaya, B., \& Tabak, A. (2018). Örgütsel Çeviklik Ölçeğinin Türkçeye Uyarlanması: Geçerlik ve Güvenirlik Çalışması. İş ve İnsan Dergisi, 5(2), 185-206.

Akkaya, B., Kayalıdere, U. K., Aktaş, R., \& Karğın, S. (2020). Çevik Liderlik Yaklaşımı ve Çevik Lider Davranışlarını Ölçmeye Yönelik Bir Ölçek Geliştirme Çalışması, 12(2), 1605-1621

Brislin, R. W. (1980). Cross-cultural research methods. In Environment and culture (pp. 47-82). Springer, Boston, MA.

Büyüköztürk, Ş. (2018). Sosyal Bilimler İçin Veri Analizi El Kitabı (Yirmi Dördüncü Baskı). Ankara: Pegem Akademi.

Cho, C. H., Kang, J., \& Cheon, H. J. (2006). Online shopping hesitation. CyberPsychology \& Behavior, 9(3), 261-274.

Close, A. G., \& Kukar-Kinney, M. (2010). Beyond buying: Motivations behind consumers' online shopping cart use. Journal of Business Research, 63(9-10), 986-992.

Çelik, Y. (2016). SPSS ile İstatistik, Biyoistatistik ve Modern Bilimsel Araştırma. İstanbul: Hünkar Ofset

Çolakoğlu, Ö. M., \& Büyükekşi, C. (2014). Açımlayıcı faktör analiz sürecini etkileyen unsurların değerlendirilmesi. Karaelmas Eğitim Bilimleri Dergisi, 2(1), 58-64.

Durmuş, B., Yurtkoru S. \& Çinko M. (2018). Sosyal Bilimlerde SPSS'le Veri Analizi (Yedinci Basım). İstanbul: Beta Basım Yayın. 
Eskin, M., Harlak, H., Demirkıran, F., \& Dereboy, Ç. (2013). Algılanan stres ölçeğinin Türkçeye uyarlanması: güvenirlik ve geçerlik analizi. In New/Yeni Symposium Journal (Vol. 51, No. 3, pp. 132-140).

Egeln, L. S., \& Joseph, J. A. (2012). Shopping cart abandonment in online shopping. Atlantic Marketing Journal, 1(1), 1.

Gorsuch, R. L. (1974). Factor analysis. Philadelphia: Saunders

Gülbahar, Y., \& Büyüköztürk, Ş. (2008). Değerlendirme tercihleri ölçeğinin Türkçeye uyarlanması. Hacettepe Üniversitesi Eğitim Fakültesi Dergisi, 35(35), 148-161.

Gürbüz S. \& Şahin F. (2018). Sosyal Bilimlerde Araştırma Yöntemleri (Beşinci Baskı). Ankara:Seçkin Akademik ve Mesleki Yayınlar

Heggestad, E. D., Scheaf, D. J., Banks, G. C., Monroe Hausfeld, M., Tonidandel, S., \& Williams, E. B. (2019). Scale adaptation in organizational science research: A review and best-practice recommendations. Journal of Management, 45(6), 2596-2627.

Huang, C. D., Goo, J., Nam, K., \& Yoo, C. W. (2017). Smart tourism technologies in travel planning: The role of exploration and exploitation. Information \& Management, 54(6), 757-770

Kapoor, A.P., \& Vij, M. (2021). Following you wherever you go: Mobile shopping 'cart-checkout' abandonment, Journal of Retailing and Consumer Services, Volume 61, 102553, ISSN 0969-6989

Kara, A. (2008). İlköğretim birinci kademede eğitimde motivasyon ölçeğinin Türkçeye uyarlanması. Ege Eğitim Dergisi, 9(2), 57-78.

Karagöz, Y. (2016). SPSS 23 ve AMOS 23 Uygulamalı İstatistiksel Analizler. Nobel Akademik Yayıncılık.

Kline, P. (1979). Psychometrics and Psychology. London. Academic Press

Kodali, S., Hult, P., Evans, F.P., \& McGowan B. (2010). Understanding Shopping Cart Abandonment, Customers Are Often Unprepared To Buy And Stunned By Shipping CostsForrester Report, https://www.forrester.com/report/Understanding+Shopping+Cart+Abandonment/-/ERES56827

Kukar-Kinney, M., \& Close, A. G. (2010). The determinants of consumers' online shopping cart abandonment. Journal of the Academy of Marketing Science, 38(2), 240-250.

Moore, S., \& Mathews, S. (2008). An exploration of online shopping cart abandonment syndrome-a matter of risk and reputation. Journal of Website Promotion, 2(1-2), 71-88.

Ntv, 2020. https://www.ntv.com.tr/teknoloji/metro-turkiyeden-yeni-dijital-alisveris-deneyimimetro-fast,k6TuH4pqIUO8I33YwSOqnQ

Oliver, R. L., \& Shor, M. (2003). Digital redemption of coupons: Satisfying and dissatisfying effects of promotion codes. Journal of Product \& Brand Management.

Özkan, A., Akkaya, B., \& Özkan, H. (2020). Hizmet Robotu Entegrasyon İsteklilik (HREİ) Ölçeği: Türkçeye Uyarlama, Geçerlik ve Güvenirlik Çalışması. Business \& Management Studies: An International Journal, 8(3), 3710-3750.

Rajamma, R. K., Paswan, A. K., \& Hossain, M. M. (2009). Why do shoppers abandon shopping cart? Perceived waiting time, risk, and transaction inconvenience. Journal of Product \& Brand Management.

Rubin, D., Martins, C., Ilyuk, V., \& Hildebrand, D. (2020). Online shopping cart abandonment: a consumer mindset perspective. Journal of Consumer Marketing.

Schreiber, J. B., Nora, A., Stage, F. K., Barlow, E. A., \& King, J. (2006). Reporting structural equation modeling and confirmatory factor analysis results: A review. The Journal of educational research, 99(6), 323-338.

Song, J. D. (2019). A study on online shopping cart abandonment: a product category perspective. Journal of Internet Commerce, 18(4), 337-368.

Statistica (2020). https://www.statista.com/statistics/457078/category-cart-abandonment-rateworldwide/

Tabak, A., Kızıloğlu, A. \& Türköz, T. (2013). Örtülü liderlik ölçeği geliştirme çalışması. Middle East Technical University Studies in Development, 40(1), 97-138. 
Tang, H., \& Lin, X. (2019). Curbing shopping cart abandonment in C2C markets - An uncertainty reduction approach. Electronic Markets, 29(3), 533-552.

Tuik (2020). Hanehalkı Bilişim Teknolojileri (BT) Kullanım Araştırması, 2020 https:// data.tuik.gov.tr/Bulten/Index?p=Hanehalki-Bilisim-Teknolojileri-(BT)-Kullanim-

Arastirmasi-

202033679\#: :text=T\%C3\%9C\%C4\%BOK\%20Kurumsal\&amp;text=\%C4\%BOnternet\%20kullan\%C4 \%B1m\%20oran \%C4\%B1\%202020\%20y \%C4\%B11\%C4\%B1nda, $\% 73 \% 2 \mathrm{C} 3 \% 20 \mathrm{oldu} \% \mathrm{C} 4 \% 9 \mathrm{Fu} \% 20 \mathrm{~g} \%$ $\mathrm{C} 3 \% \mathrm{~B} 6 \mathrm{r} \% \mathrm{C} 3 \% \mathrm{BCld} \% \mathrm{C} 3 \% \mathrm{BC}$.

Wahab, Metta Saridewi, \& Hanry Ham. "Data Transmission Using RFID System on Smart Shopping Carts for Checkout Process Efficiency in Supermarket at Indonesia." Procedia Computer Science 179 (2021): 902-912.

Xie, E., Teo, H., \& Wan, W. (2006). Volunteering personel information on the internet: effects of reputation, privacy notices, and rewards on online consumer behaviour. Marketing Letters, 17 (1), 61-74.

Xu, Y., \& Huang, J. S. (2015). Factors influencing cart abandonment in the online shopping process. Social Behavior and Personality: an international journal, 43(10), 1617-1627.

Yılmaz, K., \& Altınkurt, Y. (2013). Örgütsel iklim ölçeğinin Türkçeye uyarlanması: Geçerlik ve güvenirlik çalışması. Trakya Üniversitesi Eğitim Fakültesi Dergisi, 3(1), 1-11.

Zhao, H., Wang, X., \& Jiang, L. (2021). To purchase or to remove? Online shopping cart warning popup messages can polarize liking and purchase intention. Journal of Business Research, 132, 813-836. 


\section{Ek-1: Türkçeye Uyarlanmış Ölçeğin Son Hali}

\begin{tabular}{|c|c|c|c|c|c|c|}
\hline & & 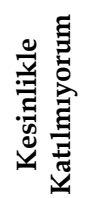 & E & 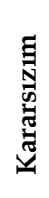 & 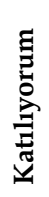 & 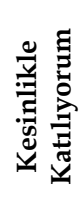 \\
\hline & Genel terk etme & & & & & \\
\hline 1 & Online alışveriş sepetimdeki ürünleri satın almaktan vazgeçtiğim olur. & & & & & \\
\hline 2 & $\begin{array}{l}\text { Online alışveriş sepetime aynı oturumda bir ürünü ekleyip sonra satın } \\
\text { almaktan vazgeçtiğim olur. }\end{array}$ & & & & & \\
\hline 3 & $\begin{array}{l}\text { Online alışveriş sepetimdeki ürünleri satın almayı tamamlamadan önce web } \\
\text { sayfasını kapattığım ya da internetten çıktığım olur. }\end{array}$ & & & & & \\
\hline 4 & Bazen Online alışveriş sepetini terk ederim. & & & & & \\
\hline & Eğlence & & & & & \\
\hline 5 & Online alışveriş sepetine ürünleri eğlence için seçip eklerim. & & & & & \\
\hline 6 & Sıkıldığımda alışveriş sepetine ürünleri seçip eklerim. & & & & & \\
\hline 7 & Alışveriş sepetini araştırma aracı olarak kullanırım. & & & & & \\
\hline & Fiziki mağaza kararı & & & & & \\
\hline 5 & $\begin{array}{l}\text { Aynı ürünü online mağaza yerine fiziki bir mağazadan satın almayı tercih } \\
\text { etmeye karar veririm. }\end{array}$ & & & & & \\
\hline 12 & Başka bir online mağazada daha indirimli ürün bulabileceğimi düşünürüm. & & & & & \\
\hline 13 & Fiziki bir mağazada daha indirimli ürün bulabileceğimi düşünürüm. & & & & & \\
\hline & Güvenlik & & & & & \\
\hline 11 & Satın almadan önce ürünün indirime girmesini beklemeye karar veririm. & & & & & \\
\hline 17 & Birilerinin kimlik bilgilerimi çalmasından endişe ederim. & & & & & \\
\hline 18 & Satıcının bilgilerimi üçüncü şahıslarla paylaşacağından endişelenirim. & & & & & \\
\hline 19 & İnternet gizliliği benim için önemidir. & & & & & \\
\hline & Maliyet & & & & & \\
\hline 14 & $\begin{array}{l}\text { Siparişimi vermeden önce kargo ücretlerini görünce satın almamaya karar } \\
\text { veririm. }\end{array}$ & & & & & \\
\hline 15 & $\begin{array}{l}\text { Siparişimi vermeden önce vergi eklendiğini görünce satın almamaya karar } \\
\text { veririm. }\end{array}$ & & & & & \\
\hline 16 & Ödeme adımında toplam tutarı görünce satın almamaya karar veririm. & & & & & \\
\hline
\end{tabular}




\section{Ek 2: Ölçeğin Orjinali}

\begin{tabular}{|c|c|}
\hline & Online cart abandonment; \\
\hline 1 & How often do you leave items in your online shopping cart without buying them? \\
\hline 2 & How often do you place an item in the online shopping cart, but do not buy it during the same Internet session? \\
\hline 3 & How often do you close the webpage, or log off the Internet before you buy the item(s) in your online shopping cart? \\
\hline \multirow[t]{2}{*}{4} & How often do you abandon your online shopping cart? \\
\hline & Decision to buy from a land-based store; \\
\hline \multirow[t]{2}{*}{5} & I decide that I would rather purchase the same item from a land-based store (as opposed to online) \\
\hline & Entertainment value; \\
\hline 6 & I select and place items in the shopping cart for fun. \\
\hline \multirow[t]{2}{*}{7} & I select and place items in the shopping cart when I am bored. \\
\hline & Using the cart as a research and organizational tool; \\
\hline 8 & I place items in the shopping cart so I can more easily evaluate a narrowed-down set of options. \\
\hline 9 & I use the shopping cart as a form of information gathering. \\
\hline \multirow[t]{2}{*}{10} & I use the shopping cart as a shopping research tool. \\
\hline & Wait for a lower/sale price; \\
\hline 11 & I decide to wait for the item to come on sale before buying it. \\
\hline 12 & I decide that I may be able to find better sales at another online store. \\
\hline \multirow[t]{2}{*}{13} & I decide that I may be able to find better sales at a land-based store. \\
\hline & Concern about the costs of the order; \\
\hline 14 & I decide not to buy when I see the shipping charges for my order. \\
\hline 15 & I decide not to buy when I see the amount of sales tax added. \\
\hline \multirow[t]{2}{*}{16} & I decide not to buy when I see the total amount at the checkout. \\
\hline & Privacy/security concerns; \\
\hline 17 & I am concerned that someone will steal my identity. \\
\hline 18 & I am concerned that the retailer will share my information with third parties. \\
\hline 19 & Internet privacy is important to me. \\
\hline
\end{tabular}

